\title{
Short Communication: Zooplankton as indicator of trophic status of lakes in Ilmen State Reserve, Russia
}

\author{
IRINA V. MASHKOVA ${ }^{1, \vartheta}$, ANASTASIYA M. KOSTRYUKOVA ${ }^{1}$, ELENA E. SHCHELKANOVA ${ }^{1}$, \\ VIKTOR V. TROFIMENKO ${ }^{2}$ \\ ${ }^{1}$ Department of Chemistry, South Ural State University. 76 Lenin Prospect, 454080 Chelyabinsk, Russia. "email: mashkovaiv@susu.ru \\ ${ }^{2}$ Department of Philosophy and Culturology, South Ural State Humanitarian Pedagogical University. 69 Lenin Prospect, 454080 Chelyabinsk, Russia
}

Manuscript received: 25 January 2021. Revision accepted: 23 February 2021.

\begin{abstract}
Mashkova IV, Kostryukova AM, Shchelkanova EE, Trofimenko VV. 2021. Short Communication: Zooplankton as indicator of trophic status of lakes in Ilmen State Reserve, Russia. Biodiversitas 22: 1448-1455. Zooplankton is a potentially powerful tool for assessing the trophic state of aquatic ecosystems. The current paper studied taxonomic composition and biomass of zooplankton communities in ten lakes within Ilmen State Reserve, Chelyabinsk region, Russia and identified the influence of trophic status on its formation. Integrated samples were taken from epilimnion in the summer of 2016-2019. Several criteria were used to determine trophic status: the taxonomic structure and biomass of zooplankton; some hydroecological indicators some hydroecological indicators and the Carlson index. The trophic status of the studied lakes, determined based on the zooplankton biomass, revealed that most of the lakes were in the status of mesotrophic. The number of zooplankton species in the lakes was 44 with Pleuroxus laevis, Bosmina longirostris, Simocephalus vetulus were the most numerous species in mesotrophic lakes; while Chaetonotus ploenensis, Keratella quadrata frenzeli, Leptodora kindti are rare. Zooplankton communities of Bolshoye Miassovo and Maloye Miassovo Lakes were characterized by high species diversity and considered as one of the most significant among the foothill lakes of the eastern slope of South Ural. The study reveals that hydroecological assessment of the ecological status is not exactly precise, as values are not stable and can change not only under the anthropogenic influence but also due to many natural abiotic environmental factors. The research shows that species composition and biomass of zooplankton communities could provide a more accurate assessment of the trophic status of water-bodies.
\end{abstract}

Keywords: Biomonitoring, foothill lakes, South Ural, trophic status, zooplankton biodiversity

\section{INTRODUCTION}

The complexity of an ecosystem is influenced by the number of species and the variety of relationships among them (Hubalek 2000). This structural complexity is largely determined by the impact of changing environmental factors, including abiotic ones. Quantitative assessment of biological diversity takes into account the richness and uniformity of the distribution of species in the community (Gilyarov 2001). These components of diversity differ in the gradients of environmental factors (Gilyarov 2001).

Biodiversity assessment is very important in environmental protection since it indicates the relationships between the structure and functioning of ecosystems which allows us to monitor and give practical recommendations regarding the state and dynamics of biotic communities (Cardinale et al. 2013). Diversity in biological systems is considered in various aspects such as richness, uniformity, diversity, and dominance of functional groups (Gilyarov 2001) depending on the task of a specific analysis. There is a concept of a direct relationship between species richness and environmental quality indicators (Sládeček 1973; Rimadiyani et al. 2019).

The concept of trophic status is widely used to characterize hydroecological state of water-bodies. The given characteristic allows assessing a water-body according to its biological productivity that is dependent on biogenic elements content. Deteriorating trophic status is crucial for many water-bodies now, as the anthropogenic impact leads to intensifying eutrophication. The Trophic State Index (TSI) designed by Robert Carlson is used to quantify a trophic status (oligo-, meso-, eutrophic) (Carlson 1977). Its calculation is based on three hydro-ecological indicators, namely water concentrations of chlorophyll $a$, total $\mathrm{P}$, and water clarity according to the Secchi disk (Carlson 1977). Carlson proposed formulas for calculating the index for each of these indicators, and each variant of calculating the index serves as a numerical measure of the trophic status of a water body (Carlson 1977).

In aquatic ecosystems, zooplankton, as an object of biomonitoring in ecological research, is a potentially powerful tool for assessing the trophic state of reservoirs (Jekatierynczuk-Rudczyk et al. 2014; Kahirun et al. 2019). This is because a complete or partial change in the zooplankton community can occur with a change in the trophic status of the reservoir (Asep et al. 2018; Jurczak et al. 2019). Studies to see the relationship of trophic level in aquatic ecosystems using quantitative and qualitative assessment of zooplankton community have been repeatedly conducted (Ejsmont-Karabin and Karabin 2013; Mashkova et al. 2019; Kostryukova et al. 2020a,b; Mashkova et al. 2020a). Despite the contradictory views on 
bioindication (Azevêdo et al. 2015; Montagud et al. 2019), the possibility of using zooplankton in environmental studies is confirmed by many authors (Jurczak et al. 2019). A comprehensive study of aquatic ecosystems takes into account the adaptation of aquatic organisms to extreme conditions of biotic and abiotic factors (Mashkova et al. 2020b). Aquatic ecosystems can be formed only in a certain range of environmental variables, which was well demonstrated in the Sladechek model (Sládeček 1973).

South Ural is a part of Russia including the Chelyabinsk, the Orenburg regions and the Republic of Bashkortostan. The Chelyabinsk region (Fig. 1) is situated at the center of Eurasia, in the South part of the Urals, on the border of two parts of the world - Europe and Asia (Government of the Chelyabinsk region). The Chelyabinsk Region is one of the oldest mining territories and endowed with rich mineral resources. The region is Russia's monopolist in the production and processing of graphite (95\%), magnesite (95\%), metallurgical dolomite $(71 \%)$, and talc $(70 \%)$. The region's industrial development is determined by the metallurgical complex, machinebuilding, fuel-and energy, construction, and agricultural sectors (Federation Council of the Federal Assembly of the Russian Federation 2021).

The South Ural is called the lake region since there are more than 3,500 lakes here. Among them, the lakes of the unified Kisegach-Miassovo hydrological system, located partially or completely within the specially protected territory of the Ilmen State Reserve, are interesting to study. These lakes are characterized by similar habitat conditions for the species but differ in trophic status. There are few works on spatial distribution, seasonal changes in population, and biomass of the zooplankton in Chelyabinsk region (Rechkalov and Golubok 2011; Rechkalov and Golubok 2011; Golubok and Rechkalov 2013; Rogozin 2018). However, the ecology of zooplankton in cold temperate lakes is very little studied. The work aims to determine taxonomic composition and biomass of zooplankton communities in the lakes within the Ilmen reserve of the Chelyabinsk region and to identify the influence of trophic status on its formation. We expected that our research can be a good contribution to add knowledge on the ecological state of zooplankton in the region and can serve as baseline information to monitor the health and quality of the aquatic ecosystems.

\section{MATERIALS AND METHODS}

\section{Study area}

This study was conducted on ten lakes in the Chelyabinsk region, Russia (Figure 1). The lakes belong to Kisegach-Miassovo hydrological system, which is almost a closed chain comprising 10 large and medium-sized lakes linked by small rivers and flowing streams. The studied lakes are under human-made impacts with various degrees, suggesting different trophic statuses.

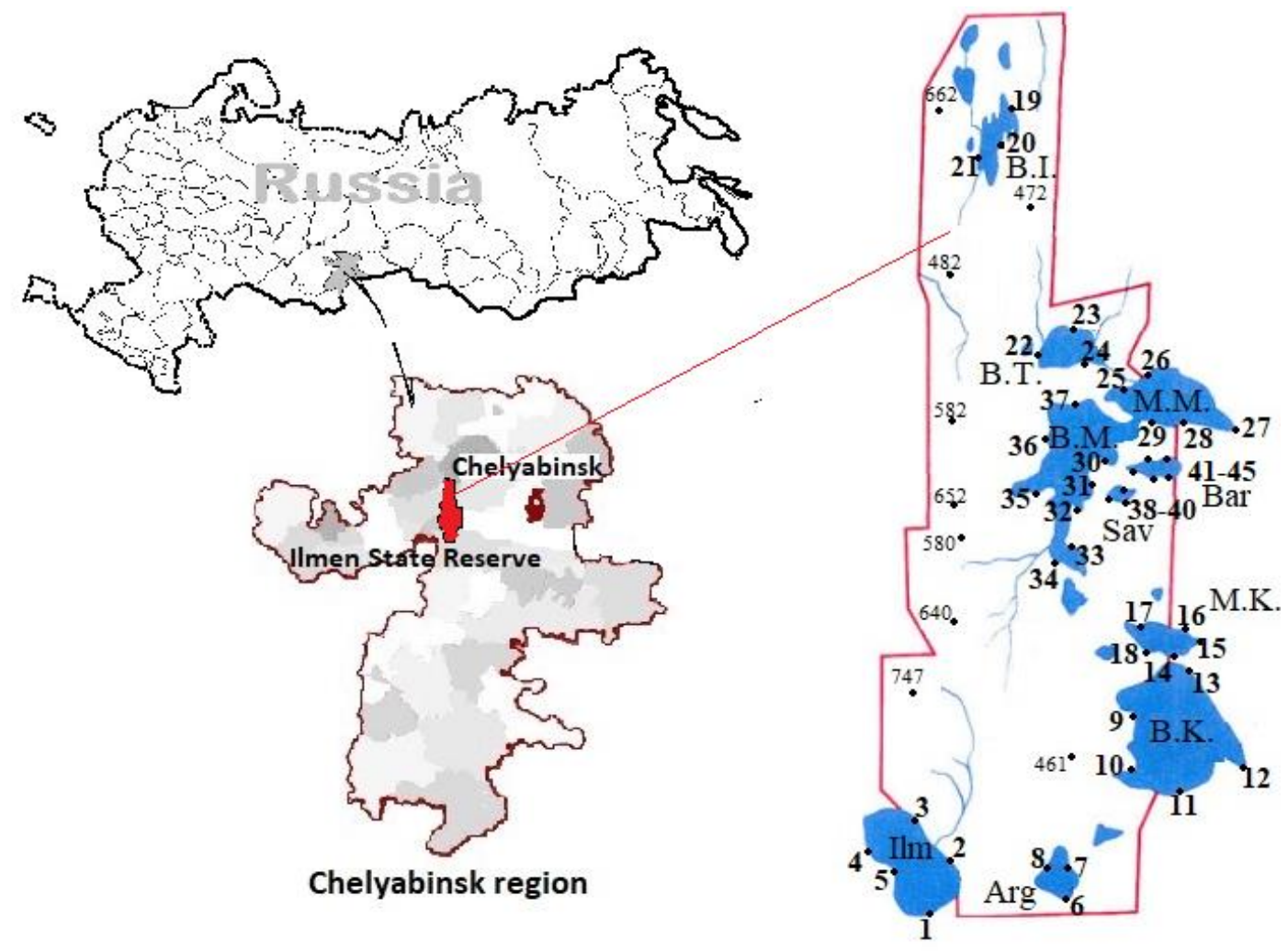

Figure 1. The map of the studied area of ten lakes in South Ural, Russia with altitudes ranging from 461 to $747 \mathrm{~m}$ above sea level. The sampling sites of each lake (coded as abbreviation) were: Ilm (1-5); Arg (6-8); B.K. (9-13); M.K. (14-18); Ishk (19-21); B.T. (22-24); M.M. (25-29); B.M. (30-37); Sav (38-40); Bar (41-45). The full names of the lakes are given in Table 1. 
Table 1. The main characteristics of the lakes in South Ural, Russia

\begin{tabular}{|c|c|c|c|c|c|c|}
\hline \multirow{2}{*}{ Lake name } & \multicolumn{2}{|c|}{ Depth (m) } & \multirow{2}{*}{$\begin{array}{c}\text { Surface } \\
\mathbf{k m}^{2}\end{array}$} & \multirow{2}{*}{$\begin{array}{c}\text { Features of the lake } \\
\text { bottom }\end{array}$} & \multirow{2}{*}{$\begin{array}{c}\text { The presence of human } \\
\text { activities }\end{array}$} & \multirow{2}{*}{ Features of the shoreline } \\
\hline & Avg & Max & & & & \\
\hline Argayash (Arg) & 2.1 & 3.2 & 1.44 & Silty, sometimes sandy & No & The shore is swampy, surrounded by pine forest growing on rocky hills \\
\hline $\begin{array}{l}\text { Bolshoy Tatkul } \\
\text { (B.T.) }\end{array}$ & 2.3 & 3.4 & 2.48 & Silty, sometimes rocky & No & $\begin{array}{l}\text { The lakeshore is sandy and rocky, mostly hilly, partly swampy, along the shore of } \\
\text { mixed forests }\end{array}$ \\
\hline Ilmenskoe (Ilm) & 3.2 & 6.1 & 4.76 & Silty & $\begin{array}{l}\text { Three villages and a } \\
\text { motorway }\end{array}$ & $\begin{array}{l}\text { The shores are flat, swampy, part of the shore is in reed thickets, some sections of } \\
\text { the shore are surrounded by natural forest and artificial forest plantations }\end{array}$ \\
\hline $\begin{array}{l}\text { Maloye Miassovo } \\
\text { (M.M.) }\end{array}$ & 4.7 & 7.8 & 12.0 & $\begin{array}{l}\text { Silty, sometimes sandy, } \\
\text { rocky }\end{array}$ & $\begin{array}{l}\text { Railway station, motorway, } \\
\text { recreation sites, children's } \\
\text { health camp }\end{array}$ & $\begin{array}{l}\text { The northern and western shores are hilly, the eastern shore is flat, the southern } \\
\text { shore is swampy, and the western and eastern shores are covered with mixed forest }\end{array}$ \\
\hline Savelkul (Sav) & 5.1 & 8.4 & 6.64 & Silty & No & $\begin{array}{l}\text { The shores of the lake are sandy and rocky, mostly flat, swampy from the north and } \\
\text { partly from the west, mixed deciduous forests along the shore }\end{array}$ \\
\hline Baraus (Bar) & 6.5 & 10.0 & 1.08 & $\begin{array}{l}\text { Rocky-pebble, } \\
\text { sometimes silty }\end{array}$ & Six villages, recreation sites & $\begin{array}{l}\text { The southern shore of the lake is hilly, covered with mixed forest with a } \\
\text { predominance of pine and birch, the northern shore is more flat and open, partially } \\
\text { overgrown with birch trees, the southern and eastern shores are swampy }\end{array}$ \\
\hline Ishkul (Ishk) & 7.9 & 15.0 & 2.7 & $\begin{array}{l}\text { Silty, sometimes sandy, } \\
\text { rocky }\end{array}$ & No & $\begin{array}{l}\text { The shores are mostly hilly, covered with coniferous-deciduous forests, } \\
\text { undergrowth vegetation is represented by fern and horsetail. }\end{array}$ \\
\hline $\begin{array}{l}\text { Maloy Kisegach } \\
\text { (M.K.) }\end{array}$ & 7.9 & 16.3 & 2.04 & Sandy & No & $\begin{array}{l}\text { The slopes of the shores are steep, rocky, covered with abundant vegetation, pine } \\
\text { forests with an admixture of birch dominate }\end{array}$ \\
\hline $\begin{array}{l}\text { Bolshoye } \\
\text { Miassovo (B.M.) }\end{array}$ & 11.3 & 22.5 & 11.4 & Silty & No & $\begin{array}{l}\text { On all sides are surrounded by hills covered with mixed and pine forest, the } \\
\text { shoreline is highly indented }\end{array}$ \\
\hline $\begin{array}{l}\text { Bolshoy } \\
\text { Kisegach (B.K.) }\end{array}$ & 18.0 & 35.2 & 14.2 & Sandy & $\begin{array}{l}\text { Several recreation sites and a } \\
\text { village }\end{array}$ & The lake shores are rocky, covered with forest, and intended by numerous bays \\
\hline
\end{tabular}


Basic information about the lakes is shown in Table 1. Lakes of the Ilmen group are located within the lowmountain and foothill zones at an altitude of 270-375 m above sea level in rows along meridionally oriented mountain ranges (Table 1). Bolshoe Miassovo, Ishkul, Bolshoy Tatkul, Argayash, Savelkul, Baraus are located on the territory of the Ilmen state reserve and can be considered conditionally undisturbed, while Maloe Miassovo, Bolshoy Kisegach, Maloy Kisegach, and Ilmenskoe are affected by anthropogenic factors because they are partially located outside the reserve (Figure 1).

\section{Sample collection}

The primary data collection was gathered as follows: in June-July 2015 the samples from Ilmenskoe and Argayash were collected; then in June-July 2016 those from Savelkul, Baraus and Bolshoye Miassovo; while in 2017 were from Maloye Miassovo, Bolshoy Kisegach and Maloy Kisegach; and in 2018-2019 were the samples from Bolshoy Tatkul and Ishkul. The zooplanktons were caught in the upper layers of the lakes using a conical plankton net with the diameter of the upper ring was $18 \mathrm{~cm}$, the lower ring was $24 \mathrm{~cm}$, and the mesh cell size was $25 \mathrm{mkm}$ ). When sampling the water column of the lakes, horizons were determined: large with an interval of $3 \mathrm{~m}$, medium with an interval of $2 \mathrm{~m}$, shallow with an interval of $1 \mathrm{~m}$. Samples from these horizons were taken using a bathometer. Integrated water samples at each site were brought to the laboratory for further research. The samples were fixed with $5 \%$ formalin, then reduced to $100 \mathrm{ml}$, three consecutive samples of $1 \mathrm{ml}$ were studied with the binocular microscope and analyzed by the standard methods in the laboratory.

The species were counted and taxonomically identified (Tsalolihin 1994; Nogrady and Segers 2006). To identify most of the species and genera, a 100-400 magnification microscope was used. To study crustaceans under a microscope, they were transferred on a slide in a drop of glycerol and placed sideward with the antennae set aside from the body, if possible. Cover glasses were equipped with modelling clay to avoid damaging large species. For the analysis, average-weighted samples were prepared for each object. The results for the number of species were expressed as the number of animals per liter. The standard counting method was used to assess the number of zooplankton species. Rare species were counted in the third, half, and whole sample depending on the size. The dominant species were identified according to the abundance in taxonomic groups of crustaceans and rotifers separately. The lake clarity value was determined by a white Secchi disk (SD) with a diameter of $30 \mathrm{~cm}$. We used Non-metric Multidimensional Scaling (NMDS) to examine zooplankton community.

\section{Data analysis}

Besides the primary data collected in this study, data of other researchers (Rechkalov and Golubok 2011; Rogozin
2018), as well as the results of our previous work, were used for analysis.

The Trophic Status Index was calculated according to the water clarity values using Carlson formula (Carlson 1977):

$$
\mathrm{TSI}=10 \cdot\left(6-\log _{2} \mathrm{SD}\right),
$$

Where: SD: water clarity according to Secchi disk, m.

The lake is classified as oligotrophic with TSI $<30-40$, mesotrophic with TSI $=40-50$, eutrophic with TSI $=50-70$, hypereutrophic with TSI $>70$.

To assess the similarity of plankton in different lakes and analyze the influence of abiotic factors on the formation of the zooplankton community, the Czekanowski-Sorensen coefficient was used, which was determined using GRAFS (Nowakowski 2004).

\section{RESULTS AND DISCUSSION}

The results of ecological variables that indicate the trophic character of the studied lakes, such as clarity and salinity, are presented in Table 2 .

Figure 2 provides the assessment of similarity of zooplankton species diversity in the studied lakes according to the Czekanowski-Sorensen Index. Looking at Figure 2, it is apparent that the species structure of the lake Argayash is close to mesotrophic lakes. So it gives us grounds to refer to the lake as mesotrophic. The lakes Ilmenskoye and Bolshoy Kisegach, which are mesotrophic by status, are similar to the eutrophic lakes Ishkul and Maly Kisegach according to the species composition, so we assume that these lakes are of the transitional mesoeutrophic status. Thus, we could classify the lakes this way: Savelkul, Baraus are oligotrophic lakes; Bolshoye Miassovo, Maloye Miassovo, Bolshoy Tatkul and Argayash are mesotrophic; Ilmenskoe, Ishkul, Bolshoy Kisegach, and Maloy Kisegach are meso-eutrophic. If the trophic status of these lakes is classified according to the index of zooplankton species diversity, it does not always coincide with the results in Table 2.

A total of 44 species of zooplankton were recorded in the studied lakes ranging from 33 in Maloy Kisegach to 43 in Bolshoye Miassovo, Maloye Miassovo and Argayash. The recorded species belong to three main taxa, namely Cladocera, Copepoda and Rotifera. Most of them are widely distributed in the temperate zone. Zooplankton communities were very similar in taxonomic composition in all the studied lakes (Table 3).

The order of Cladocera had the greatest species diversity, ranging from 15 to 18 species (from $38 \%$ to $50 \%$ of their total number). Slightly fewer species have been recorded from the Rotifera class with 9 to 17 species $(28 \%$ to $40 \%)$. In terms of species diversity, the order of Copepoda is represented almost equally in all the studied reservoirs with 9 species $(20 \%)$. 
Table 2. Results of ecological variables of the lakes in South Ural, Russia

\begin{tabular}{|c|c|c|c|c|c|}
\hline \multirow{2}{*}{ Lake name } & \multicolumn{2}{|c|}{ Salinity } & \multirow{2}{*}{$\begin{array}{c}\text { Clarity } \\
\text { (Secchi disc, } \mathbf{m} \text { ) }\end{array}$} & \multirow{2}{*}{$\begin{array}{l}\text { Trophic State } \\
\text { Index (TSI) }\end{array}$} & \multirow{2}{*}{ Trophicity } \\
\hline & $\mathrm{mg} \cdot \mathrm{L}^{-1}$ & Type & & & \\
\hline Argayash & 362,3 & $\mathrm{HCO}_{3}-\mathrm{Mg}-\mathrm{SO}_{4}$ & 1.6 & 53 & Eutrophic \\
\hline Bolshoy Tatkul & 230.1 & $\mathrm{HCO}_{3}-\mathrm{Ca}-\mathrm{Na}$ & 2.5 & 47 & Mesotrophic \\
\hline Ilmenskoe & 337.6 & $\mathrm{HCO}_{3}-\mathrm{Ca}-\mathrm{Mg}$ & 2.3 & 48 & Mesotrophic \\
\hline Maloye Miassovo & 417.0 & $\mathrm{HCO}_{3}-\mathrm{Na}-\mathrm{SO}_{4}$ & 3.7 & 41 & Mesotrophic \\
\hline Savelkul & 123.0 & $\mathrm{HCO}_{3}-\mathrm{Ca}-\mathrm{Na}$ & 4.2 & 39 & Oligotrophic \\
\hline Baraus & 115.0 & $\mathrm{HCO}_{3}-\mathrm{Ca}-\mathrm{Mg}$ & 4.5 & 38 & Oligotrophic \\
\hline Ishkul & 218.4 & $\mathrm{HCO}_{3}-\mathrm{Ca}-\mathrm{Na}$ & 1.6 & 53 & Eutrophic \\
\hline Maloy Kisegach & 298.6 & $\mathrm{HCO}_{3}-\mathrm{Ca}-\mathrm{Na}$ & 1.5 & 54 & Eutrophic \\
\hline Bolshoye Miassovo & 240.3 & $\mathrm{HCO}_{3}-\mathrm{Ca}-\mathrm{Na}$ & 3.7 & 41 & Mesotrophic \\
\hline Bolshoy Kisegach & 244.8 & $\mathrm{HCO}_{3}-\mathrm{Ca}-\mathrm{Na}$ & 4.0 & 40 & Mesotrophic \\
\hline
\end{tabular}

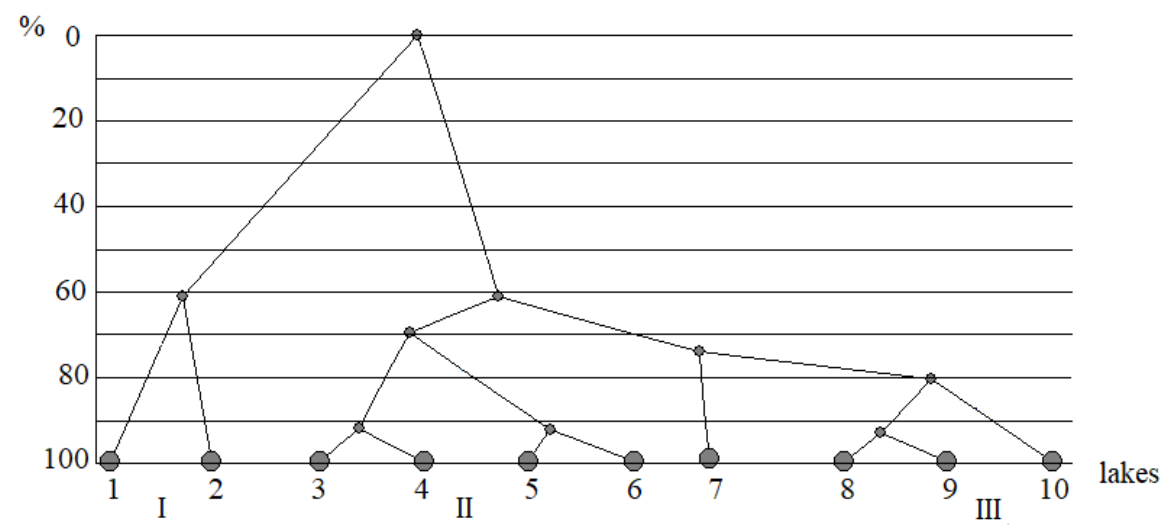

Figure 2. Ranging of the studied lakes (according to the Czekanowski-Sorensen index): I. oligotrophic lakes; II. mesotrophic lakes; III. mesoeutrophic lakes; 1. Savelkul; 2. Baraus; 3. Argayash; 4. Bolshoye Miassovo; 5. Bolshoy Tatkul; 6. Maloye Miassovo; 7. Ishkul; 8. Ilmenskoe; 9. Bolshoy Kisegach; 10. Maloy Kisegach

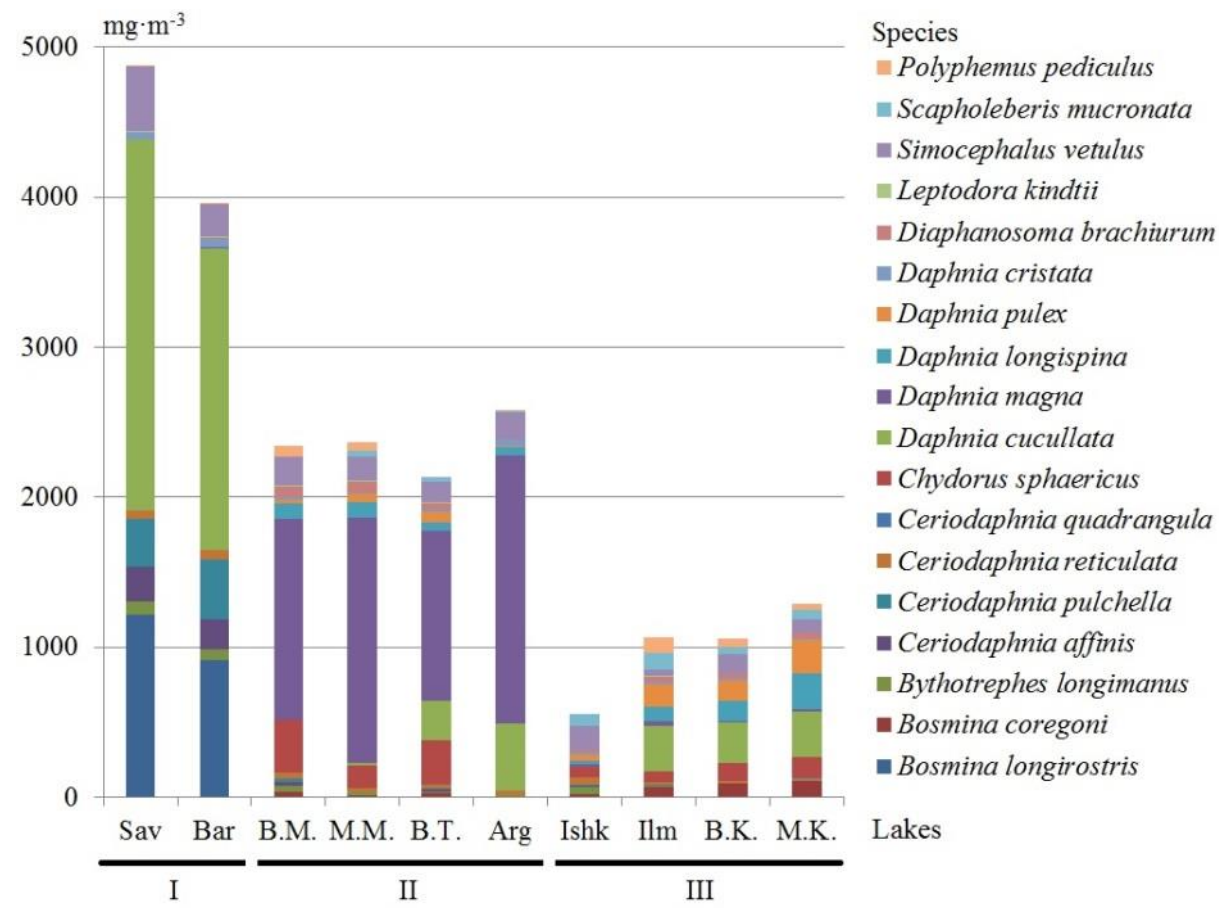

Figure 3. Ratio of Cladocera species biomass of different types of lakes: I-oligotrophic lakes; II-mesotrophic lakes; III-mesoeutrophic lakes 
Table 3. Species composition and biomass of zooplankton species $\left(\mathrm{mg} \cdot \mathrm{L}^{-1}\right)$

\begin{tabular}{|c|c|c|c|c|c|c|c|c|c|c|}
\hline \multirow{2}{*}{ Species } & \multicolumn{10}{|c|}{ Lakes } \\
\hline & Arg & Sav & Bar & B.M.. & M.M. & B.T. & Ishk & IIm & B.K. & M.K. \\
\hline \multicolumn{11}{|l|}{ Order Cladocera, Class Crustacea } \\
\hline Bosmina longirostris (O.F. Müller, 1776) & 1.58 & 1216.75 & 915.64 & 7.09 & 1.16 & 1.9 & 1.37 & 0.51 & 0 & \\
\hline Bosmina coregoni (O.F. Müller, 1785) & 4.71 & 0.33 & 1.01 & 27.39 & 14.17 & 25.86 & 14.73 & 69.81 & 88.44 & 108.61 \\
\hline Bythotrephes longimanus (Leydig, 1860) & 4.81 & 90.00 & 72.83 & 44.53 & 16.89 & 11.98 & 50.19 & 8.4 & 0 & \\
\hline Ceriodaphnia affinis (Lilljieborg, 1862) & 0.58 & 231.26 & 5192.11 & 23.69 & 0.89 & 15.37 & 7.09 & 0.66 & 0.26 & 0.43 \\
\hline Ceriodaphnia pulchella (Sars, 1862) & 1.36 & 317.92 & 405.74 & 18.17 & 1.6 & 2.47 & 8.72 & 1.03 & 0.03 & 0.05 \\
\hline Ceriodaphnia reticulata (Jurine, 1820) & 28.37 & 52.16 & 58.67 & 40.55 & 25.51 & 25.61 & 46.89 & 18.02 & 20.41 & 16.51 \\
\hline Ceriodaphnia quadrangula (O.F. Müller, 1785) & 0 & 0 & 0 & 3.66 & 3.15 & 2.41 & 1.01 & 0 & 2.38 & 3.75 \\
\hline Chydorus sphaericus (O.F. Müller, 1785) & 2.15 & 0.67 & 0.58 & 347.19 & 150.14 & 294.27 & 70.55 & 73.11 & 117.31 & 141.11 \\
\hline Daphnia cucullata (Sars, 1862) & 444.05 & 2474.24 & 2012.8 & 0.93 & 12.02 & 263.88 & 1.05 & 304.07 & 266.15 & 299.1 \\
\hline Daphnia magna (Straus, 1820 ) & 1792.86 & 0.87 & 9.81 & 1342.85 & 1638.28 & 1129.7 & 21.46 & 34.56 & 12.97 & 14.91 \\
\hline Daphnia longispina (O.F. Muller, 1776) & 52.9 & 0.17 & 0.33 & 103.7 & 105.3 & 54.4 & 21.73 & 93.87 & 137.73 & 237.73 \\
\hline Daphnia pulex (Leydig, 1860) & 12.11 & 0 & 0 & 20.4 & 50.94 & 79.33 & 39.67 & 151.27 & 136.18 & 226.49 \\
\hline Daphnia cristata (Sars, 1862) & 33.96 & 48.22 & 56.34 & 16.24 & 9.41 & 10.89 & 18.02 & 12.18 & 10.79 & 10.1 \\
\hline Diaphanosoma brachiurum (Levin, 1848) & 1.15 & 2.71 & 3.33 & 77.39 & 73.8 & 43.7 & 8.96 & 36.38 & 34.35 & 38.18 \\
\hline Leptodora kindtii (Focke, 1844) & 4.96 & 6.48 & 7.08 & 3.28 & 3.56 & 2.9 & 4.84 & 3.42 & 2.9 & 2.62 \\
\hline Simocephalus vetulus (O.F. I & 182.83 & 426.23 & 221.11 & 192.22 & 166.08 & 140.64 & 154.9 & 45.87 & 125.27 & 84.18 \\
\hline Scapholeberis mucronata $(\mathrm{O} .1$ & 2.1 & 0 & 0 & 3.01 & 33.43 & 26.71 & 85.67 & 108.02 & 47.04 & 61.57 \\
\hline Polyphemus pediculus (Linnaeus, 1761) & 13.18 & 3.64 & 1.82 & 68.64 & 58.03 & 0 & 0 & 103.48 & 51.21 & 41.36 \\
\hline \multicolumn{11}{|l|}{ Order Copepoda, Class Crustacea } \\
\hline Eucyclops & 48.61 & 116.6 & 114.53 & 50.81 & 44.86 & 58.81 & 31.3 & 3.23 & 4.01 & 8.03 \\
\hline Eucy & 5.68 & 0.21 & 0.44 & 7.92 & 11.68 & 8.96 & 3.92 & 26.36 & 19.04 & 19.48 \\
\hline Eudiapton & 107.28 & 135.35 & 175 & 51.77 & 52.95 & 40.47 & 25.16 & 14.8 & 15.39 & 9.21 \\
\hline Eudiapto & 1.8 & 6.05 & 6.7 & 2.7 & 1.55 & 1.6 & 2.3 & 0 & 0 & \\
\hline Cyc & 21.13 & 15.97 & 18.88 & 9.38 & 4.76 & 8.51 & 10.79 & 4.76 & 4.15 & 2.69 \\
\hline$C y$ & 1.63 & 0.35 & 0.44 & 8.42 & 6.11 & 6.35 & 0.05 & 40.59 & 19.56 & 16.11 \\
\hline Mes & 6.09 & 8.49 & 12.53 & 1.03 & 0 & 0 & 32 & 0 & 0 & \\
\hline$M a$ & 17.33 & 12.71 & 16.24 & 0.53 & 52.82 & 47.52 & 46.58 & 130.64 & 89.66 & 142.86 \\
\hline Thermocyclops oithonoides (Sars, 1863) & 90.03 & 230.93 & 234.54 & 184.23 & 175.06 & 57.48 & 0.75 & 5.75 & 4.57 & 1.1 \\
\hline \multicolumn{11}{|l|}{ Type Rotifera } \\
\hline Ast & 2.04 & 3.66 & 2.26 & 1.39 & 1.83 & 4.95 & 0 & 0 & 0.75 & 0.65 \\
\hline Bipalpus hudsoni & 0.04 & 0.64 & 0.56 & 0 & * & 0.23 & 0.71 & 0 & 0 & \\
\hline Brachionus diversicornis (Daday & 4.19 & 0.42 & 0.45 & 2.15 & 2.62 & 3.01 & 0.32 & 3.95 & 4.32 & 4.09 \\
\hline Brachionus calyciflorus calyciflorus (Pallas & 0.83 & 0 & 0 & 0.55 & 0.52 & 4.37 & 0.36 & 14.84 & 15.96 & 17.56 \\
\hline Diplois daviesiae (Gosse, 1886) & 0.24 & 0.69 & 0.96 & 0.65 & 0.22 & 0 & 0 & $*$ & $*$ & \\
\hline Euchlanis dilitata (Ehrenberg, 18 & 0.91 & 2.62 & 2.75 & 1.29 & 0.86 & 1.06 & 0.05 & 0.24 & 0.28 & 0.31 \\
\hline Filinia longiseta $($ Ehrenb & 1.55 & 0.63 & 0.71 & 0.53 & 0.73 & 0.54 & 0.82 & 2.31 & 2.97 & 2.75 \\
\hline Keratella cochlearis (Gosse, 1851$)$ & * & * & * & $*$ & * & * & * & $*$ & $*$ & \\
\hline Keratella ticinensis (Callerio, 1921) & 0.03 & * & $*$ & 1.1 & * & $*$ & 0 & 0 & 0 & 0 \\
\hline Keratella irregularis (Lau & 1.4 & 2.23 & 2.8 & 2.34 & 1.88 & 1.5 & 0.83 & 0 & 0 & 0 \\
\hline Keratella quadrata (O.F. & 0.3 & 0.68 & 0.64 & 0.5 & 0.34 & 0.55 & 0.19 & 0 & 0 & 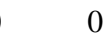 \\
\hline Kellicottia longispi & 0.12 & 0.06 & $*$ & 0.11 & 0.09 & 0.09 & 0 & 0.08 & 0.07 & 0.07 \\
\hline Lecane luna (O.F. Mu & $*$ & $*$ & $*$ & $*$ & $*$ & $*$ & $*$ & 0 & 0 & \\
\hline (M) bullo bullo & $*$ & * & $*$ & $*$ & $*$ & $*$ & $*$ & $*$ & * & \\
\hline Mytilina 1 & 0.99 & 3.52 & 3.62 & 1.77 & 1.44 & 1.29 & 0.23 & 0 & 0 & \\
\hline Notholca labis & 2.14 & 3.19 & 1.78 & 3.29 & 1.75 & 2.21 & 0.63 & 0.13 & 0.04 & 0.05 \\
\hline Trichocerca stylata (Gosse, 1851) & $*$ & $*$ & $*$ & $*$ & $*$ & $*$ & $*$ & $*$ & $*$ & \\
\hline
\end{tabular}

Note: * biomass of zooplankton species less than $0.03 \mathrm{mg} \cdot \mathrm{L}^{-1}$

Because the biomass of Rotifera representatives was negligible compared to the representatives of Cladocera and Copepoda groups, we considered the change in the biomass of representatives of these groups separate from each other in groups of lakes of different trophic status. As a result of the analysis, it was found that in lakes of different trophic status, the Cladocera biomass decreases in the direction of increasing trophic. So, in oligotrophic lakes, it had average of $4455.2 \pm 416.5 \mathrm{mg} \cdot \mathrm{L}^{-1}$, while in mesotrophic lakes it had $2355.2 \pm 228.5 \mathrm{mg} \cdot \mathrm{L}^{-1}$, and in mesoeutrophic lakes it had $1135.0 \pm 151.7 \mathrm{mg} \cdot \mathrm{L}^{-1}$ (Figure 3).

Further, in oligotrophic and mesotrophic lakes, there were core complexes of zooplankton with distinct edification species: in oligotrophic lakes, these were $B$. longirostris and D. cucullate, while in mesotrophic lakes, this was D. magna. Whereas in the mesoeutrophic lakes, the biomass of different species of representatives of Cladocera is small and slightly different (Figure 3). 
The biomass of Copepoda representatives also decreased with increasing trophic. Thus, in oligotrophic lakes, the biomass of Copepoda representatives had average of $552.9 \pm 27.5 \mathrm{mg} \cdot \mathrm{L}^{-1}$, mesotrophic lakes had $299.0 \pm 50.7 \mathrm{mg} \cdot \mathrm{L}^{-1}$, and mesoeutrophic lakes had $183.7 \pm$ $39.7 \mathrm{mg} \cdot \mathrm{L}^{-1}$ (Figure 3 ). In all of lake tropic types, there were dominant species, i.e., in oligotrophic lakes these were $T$. oithonoides, E. graciloides and E. macrurus, while in mesotrophic lakes were T. oithonoides, E. graciloides, $E$. macrurus and M. albidus and in mesoeutrophic lakes the pattern was changing with the dominant species were $M$. albidus, $C$. strenuus and E. serrulatus reach greater biomass (Figure 4).

Unlike Copepoda and Cladocera, Rotifera biomass slightly changed with increasing water tropism (in oligotrophic lakes was $16.7 \pm 1.7 \mathrm{mg} \cdot \mathrm{L}^{-1}$, in mesotrophic lakes, was $16.2 \pm 2.7 \mathrm{mg} \cdot \mathrm{L}^{-1}$, and in mesoeutrophic lakes was $23.9 \pm 1.7 \mathrm{mg} \cdot \mathrm{L}^{-1}$ ), but species diversity is reduced (Figure 4). In all types of lakes, there were dominant species, i.e., in oligotrophic lakes were $N$. labis, $M$. ventralis ventralis, $K$. irregularis, $E$. dilitata and $A$. priodonta; while in mesotrophic lakes the species of $M$. ventralis ventralis, $E$. dilitata and $A$. priodonta decreased, but $N$. labis, $K$. irregularis remained dominant, and the biomass of $B$. diversicornis increased. The edificator species $K$. irregularis and dominants $B$. diversicornis, $F$. longiseta are distinguished in the mesoeutrophic lakes (Figure 5).

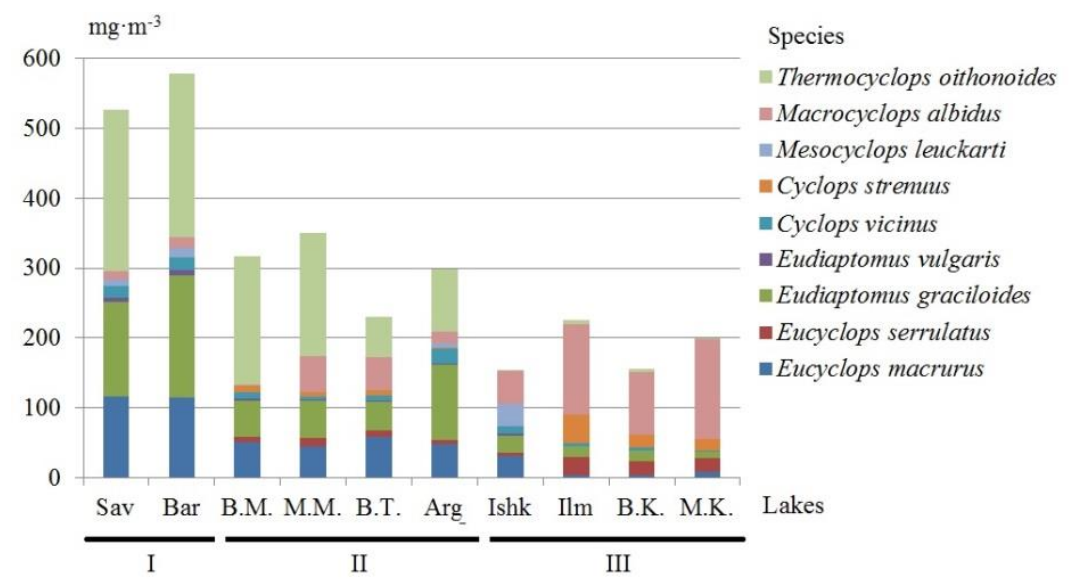

Figure 4. Ratio of Copepoda species biomass of different types of lakes: I-oligotrophic lakes; II-mesotrophic lakes; III-mesoeutrophic lakes

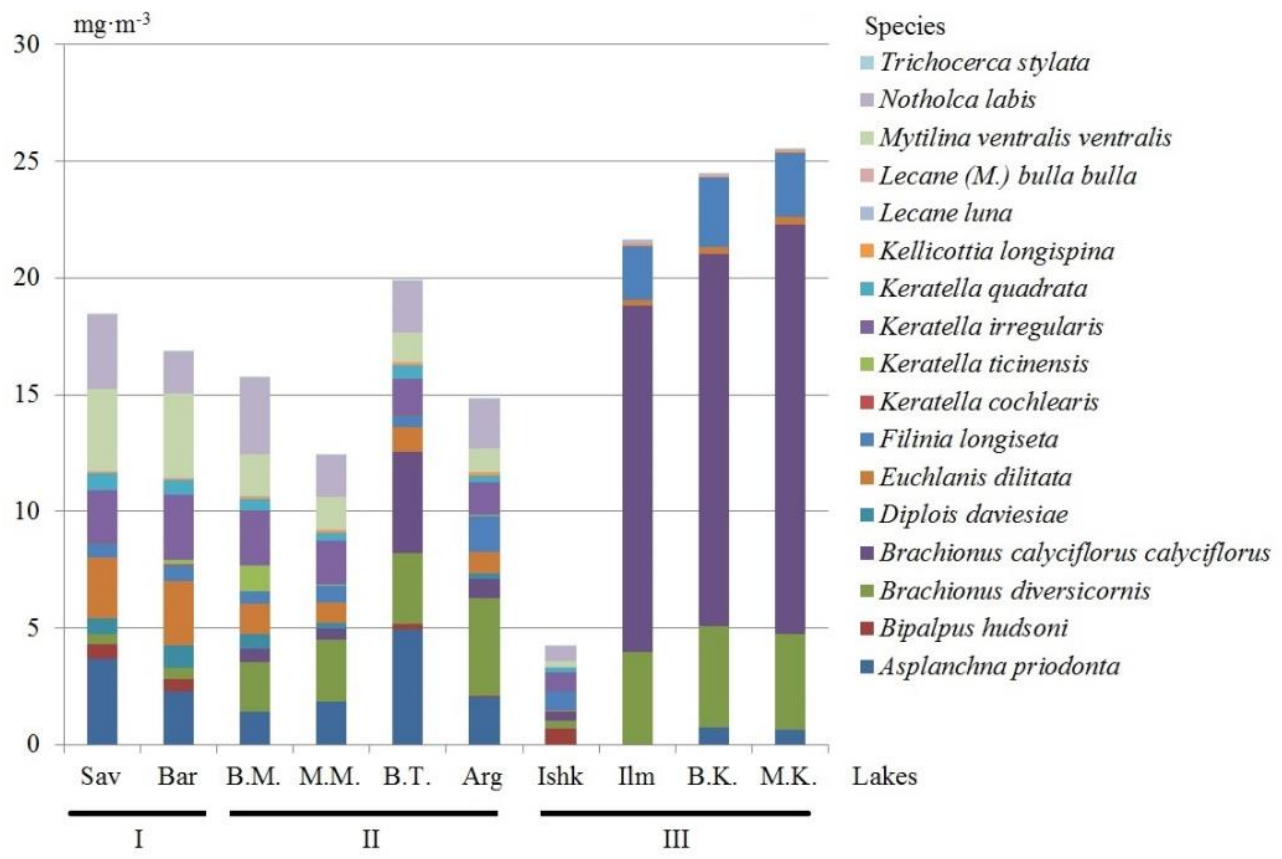

Figure 5. Ratio of Rotifera species biomass of different types of lakes: I-oligotrophic lakes; II-mesotrophic lakes; III-mesoeutrophic lakes 
Total zooplankton biomass decreased from 5430.90 $\mathrm{mg} \cdot \mathrm{L}^{-1}$ (Savelkul) to $707.67 \mathrm{mg} \cdot \mathrm{L}^{-1}$ (Ishkul) when the trophic content of water in natural fresh lakes of the unified Kisegach -Miassovo hydrological system changed in the direction of oligotrophic-mesotrophic-mesoeutrophic. If considered in separate groups, the biomass of Cladocera representatives decreased in this direction, from 4871.65 $\mathrm{mg} \cdot \mathrm{L}^{-1}$ (Savelkul) to $536.85 \mathrm{mg} \cdot \mathrm{L}^{-1}$ (Ishkul), and Copepoda from $595 \mathrm{mg} \cdot \mathrm{L}^{-1}$ (Baraus) to $163.68 \mathrm{mg} \cdot \mathrm{L}^{-1}$ (Ishkul). The biomass of Rotifera representatives varied slightly, but it was higher in mesoeutrophic lakes with $25.48 \mathrm{mg} \cdot \mathrm{L}^{-1}$ (Maloy Kisegach) than in oligo- and mesotrophic lakes with $12.31 \mathrm{mg} \cdot \mathrm{L}^{-1}$ (Maloye Miassovo).

In summary, this study suggests that the zooplankton community provides a more accurate assessment of the trophic status of reservoirs and shows their gradual transition from one status to another. The assessment of hydro-ecological indicators is not very accurate since the level of indicators is unstable and can change not only under the influence of anthropogenic factors but also depending on many natural abiotic factors of the environment.

\section{ACKNOWLEDGEMENTS}

This article was presented at the International Webinar Society for Indonesian Biodiversity \& Sebelas Maret University, Surakarta, Indonesia, 19 December 2020. This research was funded by RFBR and Chelyabinsk Region (Russia), project number 20-45-740005.

\section{REFERENCES}

Asep S, Zahidah, Herawati H, Wardiatno Y, Setyobudiandi I, Partasasmita R. 2018. Macrozoobenthos as bioindicator of ecological status in Tanjung Pasir Coastal, Tangerang District, Banten Province. Indonesia. Biodiversitas 19 (3): 1123-1129. DOI 10.13057/biodiv/d190347.

Azevêdo DJS, Barbosa JEL, Gomes WIA, Porto DE, Marques JC, Molozzi J. 2015. Diversity measures in macroinvertebrate and zooplankton communities related to the trophic status of subtropical reservoirs: Contradictory or complementary responses? Ecological Indicators 50: 135-149. DOI: 10.1016/j.ecolind.2014.10.010.

Cardinale BJ, Gross K, Fritschie KJ, Flombaum P, Fox JW, Rixen C, van Ruijven J, Reich PB, Scherer-Lorenzen M and Wilsey BJ. 2013. Biodiversity simultaneously enhances the production and stability of community biomass, but the effects are independent. Ecology 94: 1697-1707. DOI: 10.1890/12-1334.1.

Carlson RE. 1977. A trophic state index for lakes. Limnol Oceanog 22 (2): 361-369. DOI: 10.4319/lo.1977.22.2.0361.

Ejsmont-Karabin J, Karabin A. 2013. The suitability of zooplankton as lake ecosystem indicators: Crustacean trophic state index. Polish J Ecol 61 (3): 561-573.

Federation Council of the Federal Assembly of the Russian Federation. 2021. http://council.gov.ru/en/structure/regions/CHE.

Gilyarov AM. 2001. Relationship of biodiversity with productivity science and politics. Priroda 2: 20-24. [Russian]

Golubok OV, Rechkalov VV. 2013. Identifying signs of anthropogenic eutrophication of dimictic lakes by indicators of the state of zooplankton. Bull Omsk State Univ 10 (159): 61-68. [Russian]
Government of the Chelyabinsk region. https://pravmin74.ru/chelyabinskaya-oblast/vizitnaya-kartochka. [Russian].

Hubalek Z. 2000. Measures of species diversity in ecology: An evaluation. Folia Zool 49: 241-260.

Jekatierynczuk-Rudczyk E, Zieliński P, Grabowska M, Ejsmont-Karabin J, Karpowicz M, Więcko A. 2014. The trophic status of Suwałki Landscape Park lakes based on selected parameters (NE Poland). Environ Monit Assess 186 (8): 5101-5121. DOI: 10.1007/s10661014-3763-0.

Jurczak T, Wojtal-Frankiewicz A, Frankiewicz P, Kaczkowski Z, Oleksińska Z, Bednarek A, Zalewski M. 2019. Comprehensive approach to restoring urban recreational reservoirs. Part 2 - Use of zooplankton as indicators for the ecological quality assessment. Sci $\begin{array}{llll}\text { Total Environ } 653 & (25): & 1623-1640 . & \text { DOI: }\end{array}$ 10.1016/j.scitotenv.2018.08.006.

Kahirun, Laode S, Mukhtar, Laode MHK. 2019. Evaluation of land use impact on river water quality using macroinvertebrates as bioindicator in Lahumoko Watershed, Buton Island, Indonesia. Biodiversitas 20 (6): 1658-1670. DOI: 10.13057/biodiv/d200623.

Kostryukova A, Mashkova I, Shchelkanova E, Trofimenko V, Kornilova A. 2020. Analysis of water quality of rivers and reservoirs in Chelyabinsk region, South Ural. Intl J Geomate 18 (67): 120-127. DOI: $10.21660 / 2020.67 .9163$.

Kostryukova A, Mashkova I, Shchelkanova E, Trofimenko V, Maslova J. 2020 Time-space assessment of water quality of Miass river. Intl J Geomate 19 (74): 145-152. DOI: 10.21660/2020.74.66558

Mashkova I, Kostriykova A, Shchelkanova E, Trofimenko V, Slavnaya A. 2020. Study of the zooplankton community as an indicator of the trophic status of reservoirs. Intl J Geomate 19 (73): 57-63. DOI: $10.21660 / 2020.73 .5337 \mathrm{~A}$.

Mashkova I, Kostryukova A, Shchelkanova E, Trofimenko V. 2020 Influence of trophic status on zooplankton structure in Chelyabinsk region lakes (Russia). IOP Conf Ser Earth Environ Sci 612 (1): 012006. DOI: 10.1088/1755-1315/612/1/012006

Mashkova IV, Kostriykova AM, Trofimenko VV, Slavnaya AI. 2019. Study of the zooplankton community as an indicator of the trophic status of reservoirs of the Chelyabinsk Region, Russia. IOP Conf Ser Earth Environ Sci 344 (1): 012013. DOI: 10.1088/17551315/344/1/012013.

Montagud D, Soria JM, Soria-Perpiñà X, Alfonso T, Vicente E. 2019. A comparative study of four indexes based on zooplankton as trophic state indicators in reservoirs. Limnetica 38 (1): 291-302. DOI: 10.23818/limn.38.06

Nogrady T, Segers H. 2002. Rotifera 6: Asplanchnidae, Gastropodidae, Linfiidae, Microcodidae, Synchaetidae, Trochosphaeridae and Filinia (Guides to the Identification of the Microinvertebrates of the Continental Waters of the World 18). Backhuys Publ, Leiden.

Nowakowski AB. 2004. Possibilities and principles of operation of the software module "Graphs". Automation of scientific research.

Rechkalov VV, Golubok OV. 2010. The composition and characteristics of the vertical distribution of zooplankton of Malyiy Terenkul Lake (Chelyabinsk region). In: Actual problems of studying the biota of the South Ural and adjacent areas; Materials of Russian scientificpractical conference. Orsk Humanitarian and Technological Institute, Orsk, 15 November 2010. [Russian]

Rechkalov VV, Golubok OV. 2011. Vertical distribution of zooplankton thermally stratified lakes of the Chelyabinsk region. Bull Chelyabinsk State Univ 5 (220): 110-124. [Russian]

Rimadiyani W, Krisanti M, Sulistiono. 2019. Macrozoobenthos community structure in the Western Segara Anakan Lagoon, Central Java, Indonesia. Biodiversitas 20 (6): 1588-1596. DOI: 10.13057/biodiv/d200615.

Rogozin AG. 2018. Long-term dynamics of ice phenomena-an indicator of global warming in the South Ural. Water Resour 45 (5): 650-659. [Russian]

Sládeček V. 1973. System of water quality from biological sites of view. Archiv fur Hydrobiologie Suppl 7: 1-218.

Tsalolihin SY. 1994. Key to freshwater invertebrates of Russia and adjacent territories. Zoologicheskiı̌ in-t RAN, Sankt, Peterburg. [Russian] 